\title{
Pendidikan Kesehatan tentang Sosialisasi Kesehatan Remaja tentang Gizi dan Seksual di MTS Yapensa Jenggot Kota Pekalongan
}

\author{
Ida Baroroh ${ }^{1}$, Hilda Prajayanti ${ }^{2}$ \\ E mail: idamidoren@gmail.com \\ Akademi Kebidanan Harapan Ibu Pekalongan \\ Jl. Sriwijaya No. 7 Pekalongan \\ Telp/Fax (0285) 4416108
}

\begin{abstract}
Abstrak
Remaja adalah penduduk dalam rentang usia 10-19 tahun. Rentang usia remaja adalah 10-24 tahun dan belum menikah. Masa remaja merupakan periode terjadinya pertumbuhan dan perkembangan yang pesat baik secara fisik, psikologis maupun intelektual. Sifat khas remaja mempunyai rasa keingintahuan yang besar, menyukai petualangan dan tantangan serta cenderung berani menanggung resiko atas perbuatannya tanpa didahului oleh pertimbangan yang matang. Apabila keputusan yang diambil dalam menghadapi konflik tidak tepat, mereka akan jatuh ke dalam perilaku berisiko dan mungkin akan menanggung akibat jangka pendek dan jangka panjang dalam berbagai masalah kesehatan fisik dan psikososial. Tujuan pengabdian masyarakat ini adalah memberikan pendidikan kesehatan remaja tentang Gizi dan Seksual. Metode pedidikan kesehatan yang dilakukan yaitu (1) Sosialisasi dan Perijinan, (2) Melakukan Affirmasi dan Pre Test (3) Melakukan Pendidikan kesehatan remaja tentang Gizi dan seksual. (4) Evaluasi hasil kegiatan pendidikan kesehatan dengan Pre Test. Hasil kegiatan pendidikan kesehatan menunjukkan antusiasme yang tinggi ditunjukkan respon peserta yang sangat baik dalam menerima materi mengenai Pendidikan Kesehatan Remaja tentang Gizi dan Seksual serta kemauan peserta untuk bertanya. Antusiasme peserta dapat meningkatkan pemahaman siswa tentang pentingnya gizi seimbang dan kesehatan seksual ditunjukkan dengan adanya perbedaan signifikan yang positif yakni pemahaman kesehatan remaja tentang gizi dan seksual semakin baik, antara hasil Pre Test (sebelum dilakukan Pendidikan Kesehatan) dengan Hasil Post Test (setelah dilakukan pendidikan kesehatan).
\end{abstract}

Kata kunci: Pendidikan Kesehatan, Remaja, Gizi dan Seksual.

\begin{abstract}
Teenagers Are Residents In The Age Range Of 10-19 Years. The Age Range Of Adolescents Is 10-24 Years And Not Married (Who, 2014). Adolescence Is A Period Of Rapid Growth And Development Either Physically, Psychologically And Intellectually. The Special Nature Of Adolescents Are Has A Great Sense Of Curiosity, Likes Adventure And Challenges And Tends To Dare To Bear The Risk Of His Actions Without Being Preceded By Careful Consideration. If Decisions Taken In The Face Of Conflict Are Inappropriate, They Will Fall Into Risky Behavior And May Suffer Short-Term And Long-Term Consequences In A Variety Of Physical And Psychosocial Health Problems (Ministry Of Health, 2014). The Aim Of Community Service Is To Provide Adolescent Health Education About Nutrition And Sexual. Health Education Methods Carried Out Are (1) Socialization And Licensing, (2) Conducting Adolescent Health Education About Nutrition And Sexual. (3) Evaluation Of The Results Of Health Education Activities. The Results Of The Health Education Activity Showed High Enthusiasm Shown By The Participants' Very Good Response In Receiving Material About Adolescent Health Education On Nutrition And Sexual As Well As The Willingness Of Participants To Ask Questions. The Enthusiasm Of The Participants Is Expected To Increase Students' Understanding Of The Importance Of Balanced Nutrition And Sexual Health.
\end{abstract}

Keywords: Health Education, Teenagers, Nutrition and Sex. 


\section{Pendahuluan}

Menurut WHO, remaja adalah penduduk dalam rentang usia 10-19 tahun. Menurut Peraturan Menteri Kesehatan RI Nomor 25 Tahun 2014, remaja adalah penduduk dalam rentang usia 10-18 tahun dan menurut badan kependudukan dan keluarga berencana (BKKBN) rentang usia remaja adalah 10-24 tahun dan belum menikah. Jumlah kelompok usia 10-19 tahun di Indonesia menurut Sensus Penduduk Tahun 2010 sebanyak 43,5 juta atau sekitar $18 \%$ dari jumlah penduduk. Didunia diperkirakan kelompok remaja berjumlah 1,2 milyar atau $18 \%$ daru jumlah penduduk dunia (WHO, 2014).

Masa remaja merupakan periode terjadinya pertumbuhan dan perkembangan yang pesat baik secara fisik, psikologis maupun intelektual. Sifat khas remaja mempunyai rasa keingintahuan yang besar, menyukai petualangan dan tantangan serta cenderung berani menanggung resiko atas perbuatannya tanpa didahului oleh pertimbangan yang matang. Apabila keputusan yang diambil dalam menghadapi konflik tidak tepat, mereka akan jatuh ke dalam perilaku berisiko dan mungkin akan menanggung akibat jangka pendek dan jangka panjang dalam berbagai masalah kesehatan fisik dan psikososial. Sifat dan perilaku berisiko pada remaja tersebut memerlukan ketersediaan pelayanan kesehatan peduli remaja yang dapat memenuhi kebutuhan kesehatan remaja termasuk pelayanan untuk kesehatan reproduksi (Kemenkes, 2014).

Salah satu unsur yang berperan dalam mewujudkan kesehatan reproduksi pada remaja adalah status gizi. Asupan zat-zat gizi yang seimbang dan sesuai dengan kebutuhan remaja akan membantu remaja mencapai pertumbuhan dan perkembamgan yang optimal. Ketidak seimbangan antara asupan kebutuhan atau kecukupan akan menimbulkan masalah gizi lebih maupun gizi kurang (Mufida, laila, 2018).

Berbagai perubahan terjadi pada diri remaja baik itu perubahan fisik maupun perubahan psikis. Masa remaja merupakan periode pertumbuhan dan proses pematangan diri manusia, sehingga terjadi perubahan yang sangat unik dan berkelanjutan (Mufida, laila, 2018).

Pertumbuhan fisik pada remaja terjadi secaa bersamaan dengan proses matangnya organ reproduksi. Masalah gizi pada remaja akan berdampak negatif pada tingkat kesehatan, misalnya penurunan konsentrasi belajar, resiko melahirkan bayi dengan BBLR, serta penurunan kesegaran jasmani. (Mufida, laila, 2018).

Dewasa ini kita sering mendengar istilah pendidikan seks baik melalui koran, majalah radio, buku, maupun televisi. Banyaknya pendapat mengenai pendidikan seks itu membuat pengertianya menjadi kabur. Hal itu memunculkan banyak argumen mengenai makna pendidikan seks. Akibatnya tidak sedikit pula yang memahami bahwa pendidikan seks itu sebagai suatu yang tabu.

Sekolah merupakan sebuah lembaga untuk belajar dan memberi pelajaran sesuai dengan jenjang atau tingkatan. Tingkatan yang dimaksud seperti Taman Kanak-kanak (TK), Sekolah Dasar (SD), Sekolah Menengah Pertama (SMP), Sekolah Menengah Atas (SMA), Sekolah Menengah Kejuruan dan lain-lain (Muhammad. Ali. 2006).

Dari pengertian di atas menandakan bahwa sekolah menjadi sebuah tempat atau lingkungan formal untuk belajar. Dalam kaitanya dengan pendidikan, sekolah menjadi salah satu komponen yang sangat urgen. Sekolah menjadi salah satu lingkungan tempat untuk mentransformasikan nilai dan 
pengetahuan. Maka keberadaan sekolah menjadi sebuah keharusan. Namun tidak hanya berdiri saja, tetapi sekolah harus mampu di design untuk menciptakan generasi yang cerdas dan bermoral. Pendidikan seks sebagai salah satu alternatif dalam menanggulangi degradasi moral harusnya menjadi perhatian. Pendidikan seks tidak hanya menjadi wacana saja namun secara substantif mampu diterapkan di dunia pendidikan, terutama pendidikan formal. Sekolah sebagai lembaga pendidikan formal mempunyai peranan penting dalam pendidikan karena pengaruhnya besar sekali pada jiwa anak. Maka disamping keluarga sebagai pusat pendidikan, sekolah pun mempunyai fungsi sebagai pusat pendidikan untuk pembentukan pribadi anak (Ahmadi Abu, dkk, 2001).

Sudah seharusnya pendidikan seks diterapkan dalam sekolah, seperti yang sudah diterapkan di Malaysia yang mulai dari tahap pertama, anak prasekolah usia 4 tahun, kelompok usia 7-9 tahun, tahap kedua anak usia -9 tahun, tahap ketiga anak usia remaja (10-12 tahun), tahap keempat anak usia 1318 tahun dan tahap kelima anak usia 19 tahun ke atas. Adapun materi yang diajarkan meliputi; pubertas, identitas dan orientasi seks, jati diri, keluarga dan pernikahan, kekerasan dan pelecehan seksual, HIV dan Aids, mansturbasi, alat kontrasepsi dan seks dalam konteks agama, hukum dan budaya (Rasyid. Moh, 2007). Oleh karenanya pihak sekolah (Madrasah Tsanawiyah) mengharapkan adanya sosialisasi dan pendampingan kembali dalam bentuk pendidikan kesehatan dengan materi beragam agar dapat membekali siswa dan siswi tentang kesehatan gizi dan kesehatan reproduksi yang berkualitas.

\section{Metode}

Lokasi pendidikan kesehatan dipusatkan di Madrasah Tsanawiyah (MTS) Yapensa Jenggot Kecamatan Pekalongan Selatan Kota Pekalongan. Peserta diberikan pemahaman terlebih dahulu melalui tujuan penyampaian materi pentingnya gizi dan kesehatan seksual.

Metode yang diterapkan dalam pendidikan kesehatan pada kegiatan pengabdian kepada masyarakat yakni (1) Sosialisasi dan Perijinan, (2) Melakukan Affirmasi dan Pre Test (3) Melakukan Pendidikan kesehatan remaja tentang Gizi dan seksual. (4) Evaluasi hasil kegiatan pendidikan kesehatan dengan Pre Test.

\section{Hasil dan Pembahasan}

Pendidikan kesehatan remaja tentang Gizi dan Seks bagi siswa di Madrasah Tsanawiyah (MTS) Yapensa Jenggot Kota Pekalongan dapat meningkatkan pengetahuan dan pemahaman peserta yang sebelumnya tidak paham tentang materi. Dengana danya pendidikan kesehatan, diharapkan siswa-siswa dapat mengaplikasikan tentang materi kesehatan gizi dan seksual dengan benar sehingga dapat menjaga kesehatan dan terhindar dari resiko seks bebas.

Siswa adalah generasi penerus bangsa, yang memiliki potensi besar untuk pembangunan Indonesia di masa mendatang. Dengan pemahaman yang baik tentang menjaga kesehatan terutama gizi seimbang membantu menunjang keberlangsungan pembelajaran yang adekuat. Mengingat resiko free sex dikalangan remaja semakin meningkat, maka kebutuhan pendidikan seksual di sekolah semakin penting (Rasyid. Moh, 2007). 
Peserta kegiatan pendidikan kesehatan menunjukkan antusiasme tinggi selama proses pendidikan kesehatan. Antusiasme tersebut ditunjukkan dengan respon peserta yang sangat baik dalam menerima materi mengenai Pendidikan Kesehatan Remaja Tentang Gizi dan Seksual serta kemauan peserta untuk bertanya. Antusiasme peserta tersebut diharapkan dapat meningkatkan pemahaman siswasiswa tentang pentingnya gizi seimbang dan kesehatan seksual. Hal ini ditunjukkan dengan adanya perbedaan signifikan yang positif yakni pemahaman kesehatan remaja tentang gizi dan seksual semakin baik, antara hasil Pre Test (sebelum dilakukan Pendidikan Kesehatan) dengan Hasil Post Test (setelah dilakukan pendidikan kesehatan) (Grafik.1.1)

Grafik 1.1 Hasil Pre Test dan Post Test ( Evaluasi)

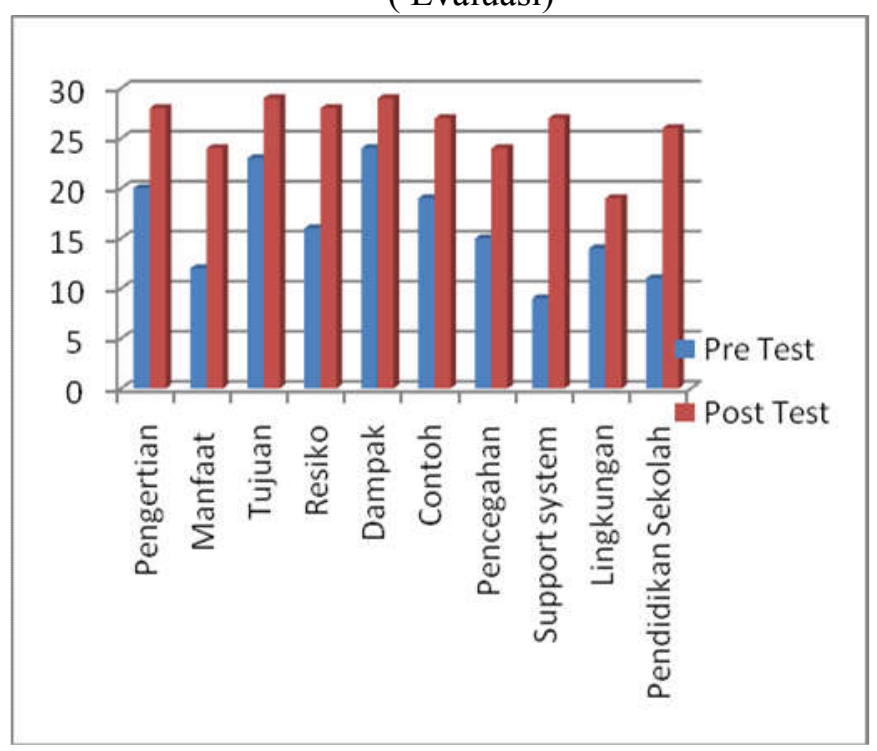

\section{Kesimpulan}

Pendidikan Kesehatan ini dapat meningkatkan pengetahuan dan pemahaman peserta tentang pentingnya gizi seimbang dan kesehatan seksual sehingga dapat menjaga kesehatan dan terhindar dari resiko seks bebas.

\section{Daftar Pustaka}

[1] Ali, Muhammad. Kamus Lengkap Bahasa Indonesia Modern: Pustaka Amani, Jakarta. 2006.

[2] Abu, Ahmadi dan Nur Uhbiyati. Ilmu pendidikan. Jakarta: Rineka Cipta.2001.

[3] Rasyid, Moh, Pendidikan Seks, Semarang : Syiar Media Publishing, 2007.

[4] WHO. Maternal Mortality : World Health Organization; 2014

[5] Kemenkes RI. Profil Kesehatan Indonesia tahun 2014. Jakarta : Kemenkes RI; 2015

[6] Laila, Mufida. Kesehatan dan Gizi Remaja. Kompasiana. 2018. 